\title{
Transforming institutions: autonomous international organisations in institutional theory
}

\author{
Jan Klabbers \\ University of Helsinki, Finland and Erasmus School of Law, Rotterdam, the Netherlands
}

This article, first delivered as the keynote at the 'Transforming Institutions' conference, discusses the increasing relevance of relations between different international organisations. It provides a discussion of what sort of forms these relations can take, and of the relevant legal questions that arise, relating to the form of instruments, treaty-making powers and procedures, accountability for joint activities, and related issues. It concludes by providing a preliminary assessment in light of some of the relevant theoretical literature.

Keywords: international organisations, law, autonomy, functionalism

\section{INTRODUCTION}

Our political-institutional imagination is very limited indeed. As soon as people try to invent practical solutions for global problems, the first thing that comes to mind is the creation of a new international organisation to address and regulate the matter. Perhaps the most striking recent example resides in the work of moral philosopher Gillian Brock. When discussing global poverty and the idea that global public goods should be financed collectively, she proposes the establishment of an international tax organisation. ${ }^{1}$ When discussing humanitarian intervention, she proposes the establishment of an international organisation to authorise legitimate interventions: a Vital Interests Protection Organisation. ${ }^{2}$ And when it comes to regulating the relationship between trade and labour, she endorses a proposal made by others for the creation of an Agency for Trade and Labour Standards, complete with the ready-made acronym ATLAS. ${ }^{3}$ Nor is she alone in this: even high authorities resort to the device of an international organisation for the solution, regulation, or management of particular issues. Thus, with respect to both climate change and financial crises it has been suggested that 'it is essential to devise stronger and more efficiently organized international institutions, with functionaries who are appointed fairly by agreement among national governments, and empowered to impose sanctions'. ${ }^{4}$ The author of those words is no lesser authority than Pope Francis, the current leader of the Roman Catholic church.

1. See G Brock, Global Justice: A Cosmopolitan Account (OUP, Oxford 2009) 137.

2. Ibid 177 .

3. Ibid 236-7.

4. See Pope Francis, Encyclical on Climate Change and Inequality: On Care for Our Common Home (Melville House, New York 2015) 107. 
What this suggests is that international organisations as a phenomenon are here to stay, if only because our political imagination is limited. Individual organisations may come and go (although they rarely disappear completely) and the designs of individual organisations may differ and range from highly complex to rather loose, ${ }^{5}$ but the notion of international organisation is firmly fixed in the human mind as the standard device for international issues that require, or are perceived to require, some kind of regulation beyond the reach or desires of national authorities. International organisations have reached, as someone like Tom Franck might have put it, their 'post-ontological phase'. ${ }^{6}$ They are taken seriously as independent global actors, so seriously indeed that member states can publicly decide to withdraw from (Brexit), resist (Trump's USA) or badmouth (Philippine President Duterte) various organisations. ${ }^{7}$ Brexit and Trumpism are symptoms of the growing autonomy of international organisations: organisations are no longer viewed as vehicles for their member states or mere agents for their principals with little or no discretion, but are increasingly seen as autonomous actors, entering independently into relations with one another and with third parties. This entails that international organisations, and in particular the law relating to them, are going through processes of transformation.

When lawyers speak of 'transforming institutions' they usually refer (and should do so lest they forget their professional mission) first and foremost to formal processes. They speak of constitutional reform and of amendment or modification of constitutive arrangements. In this vein the story of the development of the EU can be told as a succession of treaties and their amendments, starting with the original 1951 European Coal and Steel Community Treaty, followed by the European Economic Community (EEC) and Euratom treaties of 1957. After this not much happened until the Single European Act saw the light in 1986 quickly followed, after the Fall of the Wall, by the Maastricht Treaty. With pit stops in Amsterdam and Nice, this story reaches its end (for the time being) with the Lisbon Treaty.

This story would be an accurate story in its own right but also rather incomplete, and with some organisations, the story of formal amendment would not be much of a story to begin with. The UN Charter, to name an obvious example, has never been amended except on rather small points (although, in retrospect, expanding the Security Council from 11 to 15 members may have been of greater relevance than was realised at the time), and yet it is clear that the UN does many things not envisaged in the Charter or only tenuously related to it; think only of peacekeeping. ${ }^{8}$ Likewise, observing the practice of the North Atlantic Treaty Organization (NATO) bears little resemblance to NATO's constitutional document. The NATO Treaty has not been formally

5. See generally B Koremenos, C Lipson and D Snidal (eds), The Rational Design of International Institutions (CUP, Cambridge 2004).

6. Writing in the mid-1990s, Franck posited that international law need no longer demonstrate its own existence and had thus reached its post-ontological phase. See TM Franck, Fairness in International Law and Institutions (OUP, Oxford 1995).

7. The trilogy is reminiscent of Hirschman's famous 'exit, voice, and loyalty', although it may be counterintuitive to appreciate Duterte's rants against the United Nations as somehow the expression of loyalty. See AO Hirschman, Exit, Voice, and Loyalty: Responses to Decline in Firms, Organizations, and States (HUP, Cambridge, MA USA 1970).

8. For a disturbing overview of the way the Security Council has expanded its reach, see FL Kirgis, 'The Security Council's First Fifty Years' (1995) 89 AJIL 506. A more general picture of the creeping expansion of powers through seemingly technical exercises is GF Sinclair, To Reform the World: International Organizations and the Making of Modern States (OUP, Oxford 2017). 
amended but informally, through the member states adopting strategy documents and the like to give the organisation a new lease on life after its raison d'être (the threat of communism) had all but disappeared. ${ }^{9}$

Hence, the story of formal transformation, accurate as it may be, will often need to be supplemented by a story of other transformative moments. For the EU these would have to include the accession of new member states. The accession of the United Kingdom was a momentous event, as was the accession, several decades later, of a number of former communist states; both events thoroughly transformed the EU. By the same token, EU law is utterly incomprehensible without an understanding of some of the classic case-law. The nature of the EU cannot be understood without taking note of early judicial decisions such as Van Gend \& Loos, Costa $v$ ENEL, and ERTA, ${ }^{10}$ or later decisions such as Francovich - which is not to say it can be understood to begin with. On a different scale, much the same applies to the UN as well. It has almost quadrupled its membership since its inception, and while the role of international case-law is far less prominent, nonetheless advisory opinions such as Reparation for Injuries and Certain Expenses help create the legal landscape. But even so, stories of transformations (past and future) can be told in many different ways, emphasising different events, stressing different factors.

Likewise, some things only become graspable by invoking the political environment in which organisations operate. The fall of communism spurred Western European decision-makers into creating the European Union in 1992, and expanding its membership by unprecedented numbers of Eastern European states as of 2005. The development of the United Nations cannot be seen in isolation from the decolonisation movement, itself brought on by the same UN. In short, what political scientists refer to as 'organizational ecology' may, depending on the purposes of the analysis, have to be taken into account. ${ }^{11}$

This suggests three relevant considerations relating to the notion of transformation. First, transformation is rarely straightforward, and will not have a final destination. All social institutions are constantly engaged in processes of transformation, and a new court decision, or a new president or prime minister in a leading member state, can have enormous consequences. Secondly, this suggests that the sources of transformation are manifold. Transformation is not merely a matter of successive treaty arrangements - although it is that too. It is also a matter of the cumulative effects of everyday developments, which arrange and re-arrange power. One need not be a Foucauldian to appreciate that power flows not only through the arteries of treaty amendments, but also through the capillaries of everyday action, and constantly re-configures itself. Thirdly, telling the story of transformation is in itself an exercise of power; the way the story is told affects how it is received, which points are emphasised and which ignored. One may suspect that the Security Council and its permanent members have been delighted with all the hoopla surrounding never-ending discussions about Security Council reform; these have helpfully smothered other possible discussions

9. For a useful overview of the change, see S Bölingen, Die Transformation der NATO im Spiegel der Vertragsentwicklung: Zwischen sicherheitspolitischen Herausforderungen und völkerrechtlicher Legitimität (VDM, Saarbrücken 2007).

10. See already E Stein, 'Lawyers, Judges, and the Making of a Transnational Constitution' (1981) 75 AJIL 1.

11. For a recent take, see K Abbott, J Green and R Keohane, 'Organizational Ecology and Institutional Change in World Politics' (2016) 70 International Organization 247. 
about the Council's activities, including the creation of a regime of individual sanctions which, it turned out, cannot pass human rights muster. ${ }^{12}$

The point I wish to explore over the next few pages is the claim that the law of international organisations is undergoing change - or should be undergoing change. Increasingly, it seems, international organisations relate to each other, as independent, autonomous actors, and this cannot but affect the law relating to international organisations, and in particular the idea of functionalism. ${ }^{13}$ In fact, it raises a number of legal issues, both doctrinal and theoretical, and I aim to provide an overview of the challenges thus thrown up in sections 3 (doctrinal) and 4 (more theory-oriented). Before doing so, however, it may be useful to provide a brief and necessarily incomplete overview of how and why organisations cooperate with one another - this will take place in section 2, while section 5 concludes.

\section{TOWARD A TAXONOMY}

Taxonomies, as someone once quipped, tend to be as fascinating to practitioners as ornithology is to birds. ${ }^{14}$ Nonetheless, they may perform a useful function. There is little point in discussing pending legal issues without first obtaining a view, however imperfect and biased perhaps, of what it is these legal issues relate to. Literature on relations between international organisations is thus far scarce, and tends to originate in Francophone scholarship, which therewith finds itself at the vanguard of important developments. Laurence Boisson de Chazournes has provided a masterful overview of relations between universal and regional organisations, predominantly in such activities as peacekeeping where the ambitions of the UN may be assisted by regional organisations. ${ }^{15}$ In a more recent piece, the same author devoted some attention in particular to responsibility issues arising from cooperation between organisations. ${ }^{16}$ Evelyne Lagrange and Vincent Tomkiewicz, in the meantime, very helpfully produced separate book chapters on the legal principles that (ought to) govern relations between organisations, discussing the role - or possible role - of such principles as hierarchy of functions, subsidiarity, and complementarity. ${ }^{17}$ Among the very

12. The literature by now is humungous. For the argument that the Security Council may under some circumstances be disobeyed, see A Tzanakopoulos, Disobeying the Security Council: Countermeasures Against Wrongful Sanctions (OUP, Oxford 2011).

13. For related takes on institutional autonomy, see R Collins and ND White (eds), International Organizations and the Idea of Autonomy: Institutional Independence in the International Legal Order (Routledge, New York 2011). Note however that this volume encompasses several distinct concepts of autonomy, some in tension with functionalism, others rather subservient to it.

14. The quip stems from Frieder Roessler, a former legal advisor at what used to be the General Agreement on Tariffs and Trade, and is cited in HG Schermers and NM Blokker, International Institutional Law: Unity Within Diversity (4th edn, Martinus Nijhoff, Leiden 2003) 36. It seems to have disappeared from the fifth edition, published in 2011.

15. See L Boisson de Chazournes, 'Les relations entre organisations régionales et organisations universelles' (2010) 347 Recueil des Cours 79.

16. See L Boisson de Chazournes, 'Relations with Other International Organizations' in J Katz Cogan, I Hurd, and I Johnstone (eds), The Oxford Handbook of International Organizations (OUP, Oxford 2016) 691.

17. See E Lagrange, 'Les relations entre les organisations internationales' in M Vellano (ed), Il futuro delle organizzazioni internazionali: prospettive giuridiche (Editoriale Scientifica, Napoli 
few contributions thus far from the Anglo-Saxon world, some of the work of Jeff Dunoff assumes prominence. ${ }^{18}$

The topic has received more intense attention from international relations scholars but not in very satisfying ways. Much of the work done by scholars from this discipline is highly state-centric, and ignores the autonomy of international organisations therewith missing the changing variable. This work often aims to explain the behaviour of international organisations through the prism of the interests of states, and sometimes this is sufficiently persuasive. Thus, it can be argued that cooperation between the World Health Organization and the World Trade Organization on reconciling intellectual property rights and the fight against HIV/AIDS was the result of coalitions of states instrumentalising the $\mathrm{WHO}$, and in this particular case, the argument is persuasive enough. ${ }^{19}$ Likewise, the creation of the Asian Infrastructure Investment Bank (AIIB) in 2015 can plausibly be cast as China's attempt to break the Western stranglehold on the existing financial institutions and further cement Chinese power. The AIIB is in direct and overt competition with the World Bank and (to a lesser extent) the Asian Development Bank, dominated by Japan. At the same time, the first attempt to cooperate between AIIB and World Bank has already been concluded. ${ }^{20}$ Still, in addition to organisations as stages and vehicles for power struggles between states, there are numerous other more mundane forms of cooperation where such a state-centric framework is considerably less compelling. Surely, two organisations together setting up a seminar on a problem of common concern is unlikely to stem from pressure by powerful member state coalitions - instead with such activities (and many others), the driving force will be the Secretariats rather than the member states. ${ }^{21}$ Indeed, it is quite telling for the state of the art of the discipline of international relations that an award-winning book in the field could confidently proclaim as recently as 2014 that the book concerned opened up the field to the recognition that important actors in international affairs need not always be states. ${ }^{22}$

Relations between international organisations can be both cooperative and competitive, and it is useful to bear in mind that often enough cooperation and competition are closely related. One may be cooperating, for example, in order eventually to compete ('if you can't beat them, join them'), and one may compete in order to eventually cooperate ('if you can't join them, beat them'). Cooperation and competition are often

2015) 131; V Tomkiewicz, 'Concurrence, chevauchements de compétences et coordination entre organisations internationales' in E Lagrange and J-M Sorel (eds), Traité de droit des organisations internationales (LGDJ, Paris 2013) 891.

18. See JL Dunoff, 'A New Approach to Regime Interaction' in M Young (ed), Regime Interaction in International Law: Facing Fragmentation (CUP, Cambridge 2012) 136. See also JL Dunoff, 'Is Sovereign Equality Obsolete? Understanding Twenty-first Century International Organizations' (2012) 43 NYIL 99.

19. The example stems from B Faude, Von Konkurrenz zu Arbeitsteilung: Komplexität und Dynamik im Zusammenspiel internationaler Institutionen (Campus, Frankfurt am Main 2015) $122-7$.

20. See X Wu, 'Friendly Competition for Co-Progressive Development: The Asian Infrastructure Investment Bank vs the Bretton Woods Institutions' (2017) 16 Chinese JIL 41, 46-7.

21. See generally also J Mathiason, Invisible Governance: International Secretariats in International Politics (Kumarian Press, Sterling USA 2007).

22. See T Johnson, Organizational Progeny (OUP, Oxford 2014). The point itself is stunning enough; but even more telling is the author's victorious tone. 
two sides of the same coin or, perhaps more accurately, often driven by similar impulses. So what are those impulses?

One reason why organisations may cooperate - in addition to member state pressure of the sort mentioned above - is to cover the cracks that remain in a system characterised, as is the landscape of international organisations, by functional differentiation. A fine example is this. The International Labour Organization (ILO) occupies itself with labour issues, and has done so since 1919. The International Maritime Organization (IMO) is busy with maritime matters. Inevitably, this division of labour raises the question: which of them should address the labour situation of sailors and other seafaring labourers? One solution would have been for both to devise their own regimes coherent with their general approaches to labour and maritime matters generally, but the more obvious option was to cooperate and decide on jurisdiction. In the end it is the ILO that regulates the labour position of seafarers through a number of conventions, in particular the 2006 Maritime Labour Convention.

The logic is, however, not ironclad, and another example involving the ILO may illustrate the point. One may wonder whether it is the ILO or the International Organization for Migration (IOM) which ought to regulate the labour position of migrant workers. In the end neither does so; the ILO adopted some instruments in the 1970s, but nothing much since. The IOM has not done much to begin with, and while the General Assembly (that is, the UN) has sponsored a convention on the human rights of migrants, this is among the least successful of UN conventions. It has entered into force but is not in force for any migrant-receiving state. Hence, the position of migrant workers (including their labour position) has remained in limbo, falling through the cracks in a global system of functional differentiation. ${ }^{23}$

A second reason for organisations to cooperate is in order to pool their resources. A fine example can be found with respect to the international financial institutions. When presented with bids for public funding these will typically have to decide whether the companies involved in the bid are solvent and trustworthy and, not unimportantly, whether those companies do not engage in bribery and corruption. Yet the smaller institutions are too small to launch their own investigations. As a result, a so-called debarment agreement has been concluded between a number of these and the World Bank, to the effect that findings will trickle down and be adopted by the other participating financial institutions. ${ }^{24}$

Something similar applies in the field of debt relief, where states cooperate in the highly informal Paris Club, and take decisions on debt relief which are dependent on whether the state concerned receives the green light from the International Monetary Fund (IMF) - and this it will receive if it pledges to accept the IMF's policy prescriptions. Intriguingly, an effort from within the IMF itself made 15 years ago to centralise debt relief negotiations with the IMF as the formal focal point were rapidly shot down. The lack of efficiency stemming from having two entities involved (IMF and Paris Club) is most likely considered to be outweighed by the advantage of being able to move between institutions, where the Paris Club has the considerable political advantage of being opaque and little-known. The story does not end here; in recent years the

23. The cracks are not often studied; more common is to study collisions between regimes, and one of the leading examples (despite having been written in German) is A Fischer-Lescano and G Teubner, Regime-Kollisionen: Zur Fragmentierung des globalen Rechts (Suhrkamp, Frankfurt am Main 2006).

24. 'Agreement for Mutual Enforcement of Debarment Decisions' (9 April 2010) <http:// www.ebrd.com/downloads/integrity/Debar.pdf> accessed 27 May 2017. 
General Assembly and the United Nations Conference on Trade and Development have also taken initiatives on debt relief, in moves that can be seen as manifesting either cooperation or competition between organisations - or both at the same time. ${ }^{25}$

Probably the most obvious modality of cooperation between organisations is 'mutual assistance'. This classically involves such activities as peacekeeping, with regional organisations acting on the authorisation or request of universal organisations. There are also other examples. One is the International Telecommunications Union and the International Civil Aviation Organization collaborating in order to develop a way for air passengers to be able to use their mobile phones while flying and without interrupting the communication between pilots and traffic towers. ${ }^{26}$ Another is the G20 asking the Organisation for Economic Cooperation and Development (OECD) to address the issue of tax evasion by multinational companies (under the somewhat euphemistic heading of 'Base Erosion and Profit Shifting') and the OECD happily complying.

Traditionally the most self-evident way of coordinating the behaviour of functional entities is by providing for some kind of coordination mechanism. The League of Nations Covenant already included a provision to this effect in Article 24, calling on states to submit the international organisations (bureaux, in the jargon of the day) of which they were members to the direction of the League. This, however, remained rare: only six organisations accepted the invitation, none considered to be among the politically salient entities. ${ }^{27}$

Still the effort was reproduced in Article 57 of the UN Charter, and with considerably more success. Most of the leading (quasi-)universal international organisations stand in a particular kind of relationship to the UN. The latest to join the UN family is the IOM, joining in 2016. However the precise legal nature of the relationship is not entirely clear. While 'the UN family' engages in coordination efforts, the question remains whether things go much further. The ICJ in 1996 aimed to flesh out a more organic relationship, stipulating that the powers of the WHO were in part dependent on its place within the UN family with accompanying division of labour between the specialised agencies and the UN. However by general acclamation its attempt was not particularly compelling holding that the powers of one organisation depend in part, on those of others, remains difficult to reconcile with the fundamental structure of international law, where each treaty (and thus each international organisation) remains res inter alios acta: a thing between the parties only. ${ }^{28}$

If the UN family forms a relatively formalised network of organisations, less formalised networks also exist, even to the point of being so informal that a secretariat is lacking. An eye-catching example is the Contact Group on Piracy off the Coast of Somalia, which comprises a number of international organisations (including the EU, NATO, the Arab League, the African Union and the IMO) in addition to states and civil society actors such as churches, seafarers' organisations and, as one might expect, Lloyd's of London. It was set up under auspices of the UN, but is not an organ or subsidiary thereof.

25. See J Klabbers, 'On Functions and Finance: Sovereign Debt Workouts and Equality in International Organizations Law' (2016) 41 YJIL 241.

26. See Dunoff, 'A New Approach to Regime Interaction' (n 18) 162.

27. They included such stalwarts as the International Exhibitions Bureau and the International Central Office for the Control of Liquor Traffic in Africa. See W Meng, 'Article 57' in B Simma et al (eds), The Charter of the United Nations: A Commentary (2nd edn, OUP, Oxford 2002) 944, 952.

28. See J Klabbers, 'Global Governance at the ICJ: Re-reading the WHA Opinion' (2009) 13 Max Planck YB of UN L 1, 22. 
In addition to mutual assistance and networks, cooperation can also take the form of new entities. Classic examples are how the Food and Agricultural Organization (FAO) and UN together set up the World Food Programme (WFP), or how the UN Environment Programme (UNEP) and the World Meteorological Organization together established the Intergovernmental Panel on Climate Change, ${ }^{29}$ or how the WHO and FAO together set up the Codex Alimentarius Commission, whose standards moreover receive legal force by being incorporated in World Trade Organization (WTO) agreements. ${ }^{30}$ If the international legal status of these entities remains uncertain (they may lack international legal personality, probably by design), there is at least one example known of a formal international organisation established by existing international organisations. The entity in question is the Joint Vienna Institute, set up in the mid1990s to help train eastern European officials in the ways and means of market economies. ${ }^{31}$ Casting the net a little wider may result in spotting the existence of entities jointly established by international organisations, states and the private sector. These exist predominantly in the medical sphere, where international organisations can offer expertise, states can offer political power, and the private sector contributes capital; examples include UNAIDS and the GAVI Alliance.

Sometimes cooperation between organisations is predominantly administrative in nature. Thus, a well-known example (it resulted in an advisory opinion of the ICJ) is the housing of the secretariat of the convention against desertification in, and its administration by, the International Fund for Agricultural Development (IFAD). Less well-known, and potentially more problematic, is the circumstance that the World Intellectual Property Organization (WIPO) and the International Union for the Protection of New Plant Varieties (UPOV) are located in the same premises and share the same management, including their director-general.

Competition between organisations can take place in various ways as well. One example was already noted: the establishment of the AIIB as a competitor to the World Bank and the Asian Development Bank. It is by no means the only example. The creation of NATO, in 1949, was responded to by the creation of the Warsaw Pact. The establishment of the EU even resulted in two separate responses; Western European non-members set up the European Free Trade Area (EFTA), while in the eastern part of Europe the Council for Mutual Economic Assistance (CMEA, or Comecon) was created. The latter, like the Warsaw Pact, did not survive the fall of communism; EFTA, however, still exists, and might soon have to decide on a possible re-application for admission by one of its former members: post-Brexit Britain.

Organisations also compete with each other in the field. Every international incident of some magnitude will bring representatives of a variety of international organisations to the spot, and they will all vie for a piece of the action and claim that at least part of the task is within their functional jurisdiction. Thus, a famine in East Africa may involve FAO, IFAD, and the WFP for agricultural advice and food relief, if children are involved (as is likely) UNICEF may enter the picture, perhaps followed by UNESCO worrying about education and cultural degradation. For refugee flows the UN High Commissioner for Refugees (UNHCR) will appear, perhaps in tandem or

29. For background, see Johnson, Organizational Progeny (n 22) 103-85.

30. See M Masson-Matthee, The Codex Alimentarius Commission and its Standards (TMC Asser Press, The Hague 2007).

31. It was set up by a number of financial institutions together with Austria: see 'A Brief History of the JVI' (Joint Vienna Institute) <http://www.jvi.org/about/history.html> accessed 8 July 2017. 
in competition with IOM. Should the political situation destabilise, the African Union might be tempted to send troops, and so might NATO or the UN or even the EU, et cetera. ${ }^{32}$

If turf battles are the bread and butter of bureaucracies, whether domestic or international, less well-known is the situation of organisations exercising some form of control over each other. Nonetheless, the Kadi saga before the Court of Justice of the EU can be seen in this light, ${ }^{33}$ with the CJEU eventually (and somewhat backhandedly) suggesting that a Security Council resolution could not be accepted. Less prominent but at least as interesting is the attempt by the Parliamentary Assembly of the Council of Europe to hold the WHO to account over its handling of the avian flu. ${ }^{34}$

\section{DOCTRINAL QUESTIONS}

Relations between international organisations provoke a host of legal issues, but only two of those issues have met with some attention in the legal literature and even then in a limited manner, limited mostly to the external relations of the EU. It was not always thus; the first major contributions on treaty-making powers by international organisations were general in nature, typically including a discussion of what was then still the $\mathrm{EC}$, but in aspiration covering international organisations generally. ${ }^{35}$ And possibly the leading specialised study, focusing on a single organisation, was devoted to the UN rather than the EC: Rosenne's 1954 Hague Lectures. ${ }^{36}$

This is no longer the case. Studies of the treaty practice of international organisations have come to be overshadowed by the EU, for the good practical reason (but dubious academic reason) that the EU has a burgeoning treaty practice, is reasonably meticulous in publishing it, and boasts a set of courts that can shed light on the relevant legal questions. The EU is the only organisation for which there is a wealth of materials available, and thus it is the only organisation that gets studied in some depth. The treaty practice of the EU plays a central role in general works on the EU's external relations $;{ }^{37}$ is subjected to studies of specific topics (in particular perhaps the puzzling phenomenon of mixed agreements) $;^{38}$ is central to the study of relations between the

32. Some telling examples are listed in G Hancock, Lords of Poverty (Mandarin, London 1989). 33. Admittedly, the Kadi saga can be seen in many different lights and as authority for many different propositions. See Case C-402/05 Kadi v Commission [2008] ECR I-6351.

34. See A Deshman, 'Horizontal Review between International Organizations: Why, How and Who Cares about Corporate Regulatory Capture' (2011) 22 EJIL 1089; E Benvenisti, The Law of Global Governance (Hague Academy of International Law, The Hague 2014) 271. Reportedly, the Council of Europe Assembly was also instrumental in forcing the first President of the EBRD, Jacques Attali, to step down.

35. See, for example, K Zemanek, Das Vertragsrecht der internationalen Organisationen (Springer, Wien 1957); JW Schneider, Treaty-making Power of International Organizations (Droz, Geneva 1959); H Chiu, The Capacity of International Organizations to Conclude Treaties, and the Special Legal Aspects of the Treaties So Concluded (Martinus Nijhoff, The Hague 1966); K Zemanek (ed), Agreements of International Organizations and the Vienna Convention on the Law of Treaties (Springer, New York 1971).

36. See S Rosenne, 'United Nations Treaty Practice' (1954/II) 86 Recueil des Cours 275.

37. See, for example, P Koutrakos, EU International Relations Law (2nd edn, Hart, Oxford 2015).

38. See J Heliskoski, Mixed Agreements as a Technique for Organizing the International Relations of the European Community and Its Member States (Kluwer Law International, The Hague 2001). 
EU and international legal order, ${ }^{39}$ and is even analysed in light of the international law of treaties. ${ }^{40}$

Much the same applies to the second question that has traditionally received some attention; the question as to the role of the EU as a member of other organisations. ${ }^{41}$ As the EU is by and large, the most prominent example of an international organisation that actually has joined other organisations, or even helped to found them, as with the WTO, the attention here is easier to justify. And even for organisations of which the $\mathrm{EU}$ as such is not a member, the powerful position of some of the EU member states within such organisations all but guarantees some academic attention. The textbook example is the UN, whose Security Council counts two EU member states as permanent members - at least for the moment. ${ }^{42}$

\subsection{Instruments}

Other legal questions have remained rather under-studied. These include questions relating to the precise modes of cooperation and the legal status thereof. Within the UN family, the instruments through which the specialised agencies establish their relationship with the UN are usually referred to as agreements. This is the label used in Article 63 UN Charter - which lays down, in embryonic form, the treaty-making procedure to be followed within the UN - and this is the label also given to the agreement with the IOM, the most recent agreement to have been concluded. There can be little doubt that these agreements are legally binding under international law, and are intended to be so binding. The agreement is not creative of any spectacular or far-reaching obligations on either side, but some obligations can nonetheless be identified. Thus, the agreement, in Article 5, gives the Secretary-General of the UN the right to attend meetings of the IOM plenary and, conversely, grants a right to the Director-General of the IOM to attend General Assembly meetings. These rights cannot just be ignored, and neither can the right of IOM staff to make use of the UN laissez-passer as a valid travel document, a facility provided for in Article 11. The agreement is, moreover, deemed upon signature to 'enter into force' (Article 16) - and some suggest that such a phrase is typical for instruments intended to have international legal effect. ${ }^{43}$

With other instruments things may be less clear, mostly because some international lawyers have endorsed the idea that some instruments may be politically binding but not legally binding. ${ }^{44}$ There are strong arguments available against such a conception, both systemic and doctrinal (no court has ever accepted the proposition), ${ }^{45}$ but nonetheless,

39. See M Mendez, The Legal Effects of EU Agreements: Maximalist Treaty Enforcement and Judicial Avoidance Techniques (OUP, Oxford 2013).

40. See D Verwey, The European Community, the European Union and the International Law of Treaties (TMC Asser Press, The Hague 2004).

41. See R Frid, The Relations Between the EC and International Organizations: Legal Theory and Practice (Kluwer Law International, The Hague 1995).

42. See J Wouters et al (eds), The United Nations and the European Union: An Ever Stronger Partnership (TMC Asser Press, The Hague 2006).

43. See especially A Aust, Modern Treaty Law and Practice (2nd edn, CUP, Cambridge 2007).

44. The most vocal proponent is Aust (n 43).

45. See J Klabbers, The Concept of Treaty in International Law (Kluwer, London 1996). For a discussion of relatively recent case law, see J Klabbers, 'International Courts and Informal International Law' in J Pauwelyn et al (eds), Informal International Lawmaking (OUP, Oxford 2012) 219. 
amongst international lawyers the idea has gained a foothold. As a consequence, cooperation cast in the form of a 'declaration', for example, may or may not be legally binding - although even if not intended to be legally binding, such agreements may still acquire legal force through doctrines of estoppel or legitimate expectations. ${ }^{46}$ Not surprisingly perhaps, much cooperation between organisations is cast in the form of instruments with labels which do not immediately suggest legally binding force, as this provides the authorities concluding them with maximum leeway and wriggle room: such instruments need not pass through specified procedures, and are deemed unenforceable as a matter of law.

The 2016 agreement through which IOM joined the UN family was not the first involving the two organisations. It was preceded by a cooperation agreement concluded in 1996 and updated in 2013, and the IOM has also concluded separate agreements with more or less independent parts of the UN system. Thus, in 1997 it concluded a Memorandum of Understanding (MoU) with UNHCR, while in 2012 a cooperation agreement was concluded with the UN Office on Drugs and Crime (UNODC). The MoU with UNHCR was, its designation notwithstanding, in the nature of a framework agreement: its fifth provision provided for the conclusion of ad hoc Letters of Understanding to 'cover specific operational situations'. ${ }^{47}$

\subsection{Powers}

Constitutions of international organisations are, as a rule, not very specific on interorganisational cooperation. The Statute of the Council of Europe for example provides nothing on such cooperation. As a consequence, those who argue that organisations only have the powers to exercise tasks delegated to them, may have a hard time arguing how the Council of Europe can legally justify cooperation with other organisations. With other organisations often something is provided for, but usually in quite opaque terms. Article V of the Agreement establishing the WTO provides for 'appropriate arrangements for effective cooperation with other intergovernmental organisations that have responsibilities related to those of the WTO'. It does not spell out which other organisations can be partners or have related responsibilities, what 'appropriate arrangements' means both in form and in substance, nor what 'effective cooperation' means. Hence it leaves considerable leeway, and there will be few proposed agreements that would be considered ultra vires on the basis of Article V. Likewise, the much older Article 12 ILO, while it seems to facilitate joining a club such as the UN family, rather opaquely provides that the ILO may 'cooperate' with 'public international organizations having specialized responsibilities in related fields'. The form and substance such 'cooperation' may take are, as with the WTO, left unspecified; at best, Article 12 ILO suggests that substantively, any cooperative effort should stay 'within the terms' of the ILO Constitution. The provisions of the IOM Constitution are, arguably, even less specific. Article 1(2) holds that the organisation 'shall cooperate closely' with other organisations working in related fields in order to

46. As conceded by Aust: see A Aust, 'The Theory and Practice of Informal International Instruments' (1986) 35 ICLQ 787, 810-12.

47. 'Memorandum of Understanding between the United Nations High Commissioner for Refugees and the International Organization for Migration' (UN High Commissioner for Refugees, 15 May 1997) <http://www.refworld.org/docid/3ae6b31a70.html> accessed 29 May 2017. 
'facilitate the co-ordination of international activities'; this co-operation 'shall be carried out in the mutual respect of the competences of the organizations concerned' ${ }^{48} \mathrm{Be}$ this as it may, a general idea as regards both form and content is lacking. It has sometimes been observed that the law of international organisations would be well-advised to develop a system of 'secondary law' - this is typically one of the issues where such a system would be useful. ${ }^{49}$

\subsection{Procedures}

Something similar applies to the related topic of treaty-making procedure. In few organisations (with the exception of the EU) is this spelled out in any detail. Even the UN Charter's provisions on agreements relating to the UN family are not particularly finegrained. Article $63 \mathrm{UN}$ Charter seems to prescribe a two-pronged procedure: on the part of the UN, such agreements are internally approved by the General Assembly and entered into by the Economic and Social Council (ECOSOC). This leaves several questions unanswered. Given that ECOSOC is a large body, someone will have to conduct the negotiations on its behalf; typically this will be the UN Secretariat, but nowhere is this spelled out. By the same token, the agreements are usually signed on behalf of the UN by the Secretary-General. However in the grand scheme of the Charter, the Secretary-General is not organically related to ECOSOC; instead, he (apologies for the masculine form - the Charter thinks exclusively in masculine terms) is the Head of the Secretariat which hierarchically exists alongside ECOSOC both are 'principal organs' of the UN. Obviously, from a practical perspective the arrangement makes sense, but it would be stretching things to claim that it follows the letter - or even the spirit - of the Charter.

Note that with the abovementioned examples of the WTO and the ILO, even less is mentioned in any explicit manner. The ILO Constitution does not address issues of treaty-making procedure at all, and neither does the IOM Constitution. The WTO Agreement designates one of the WTO's plenary bodies (the General Council) as the organ responsible for making the 'appropriate arrangements' mentioned in Article V WTO, but it does not indicate who shall negotiate such arrangements, and whether further approval is required. The situation is much the same in other international organisations: there is little clarity about which organ would be empowered to conclude which kind of agreements on which kind of topics with which kind of partner following which kind of procedure.

\subsection{Governance}

A separate issue concerns the governance of newly created entities. This is to be sure, a general concern, and resonates in particular where the entity is a mix of private and public entities, as is the case with the GAVI Alliance. The power of the purse being a powerful concept, there is often a suspicion here that it is the private sector participants calling the shots, and rumour has it that the influence of Bill Gates (through the Bill and Melinda Gates Foundation) on various entities set up with the WHO is so substantive

48. Note how the latter sentence is grammatically awkward.

49. For the suggestion see the excellent study by I Feichtner, The Law and Politics of WTO Waivers: Stability and Flexibility in Public International Law (CUP, Cambridge 2012) 163-6. 
that when discussions need to take place, it is WHO delegates who take the plane to Seattle. But even where the private sector is not a formal partner, there are many organisations that depend on private sector contributions, UNHCR being a prominent example. It receives its funding on a voluntary basis both from states and the private sector there are no compulsory member state contributions. It is sometimes suggested that for the organisation concerned this is a good thing - it would lessen the degree of member state control. ${ }^{50}$ This however is a spurious argument. Absent compulsory contributions, the organisation is fully dependent on what its main donors wish to use it for.

If this exists with respect to well-established entities, it also exists with respect to more recent creatures. Few people, for instance, will have any intimate knowledge of the way the Contact Group on Piracy off the Coast of Somalia operates. Admittedly it will have little problems attracting funding: piracy in the area is such a threat to Europe's trading routes that the funding of (quasi-)military operations should not pose insurmountable difficulties, but its governance raises a number of questions. Who takes the decisions? How? On the basis of whose input? Who sets the agenda?

\subsection{Accountability}

These issues of governance naturally shade into questions of responsibility or accountability. Public administration scholars and others have long since identified the 'problem of the many hands'. Where actors cooperate they share their workload, but this sharing of the load may - and often does - result in a dissipation of responsibility. It becomes unclear who is responsible for what part of the activity, both in terms of accomplishing it, and in terms of attribution when things go wrong. ${ }^{51}$ The problem is well-known from peacekeeping and related activities, which typically involve troops from a number of states, operating under their own rules of engagement, but with authorisation or on request of the relevant international organisation. The International Law Commission has elaborated a sophisticated (or maybe just complicated) set of rules and principles devoted to the issue, but these are of limited practical use, in that the scope of the articles is restricted to settings involving relations between organisations or with third states - the effects of organisational activities on anyone other than states or organisations (that is, on you and me) is left out of the scope of application of the articles on the responsibility of international organisations. ${ }^{52}$

\subsection{Delegation}

Finally, as the increasing autonomy of international organisations often results in existing organisations delegating tasks to newly created entities or programmes, the question is raised where and how the concept of delegation works in international

50. The argument is made with much enthusiasm in Johnson, Organizational Progeny (n 22), for example, at 53, 76-7.

51. See L May, Sharing Responsibility (University of Chicago Press, Chicago 1992); M Bovens, The Quest for Responsibility: Accountability and Citizenship in Complex Organisations (CUP, Cambridge 1998); A Nollkaemper and D Jacobs (eds), Distribution of Responsibilities in International Law (CUP, Cambridge 2015).

52. For useful discussion, see M Ragazzi (ed), Responsibility of International Organizations: Essays in Honour of Sir Ian Brownlie (Martinus Nijhoff, Leiden 2013). 
organisations law. This too is a question that has received fairly little attention thus far. Sometimes delegation is analysed in $a d$ hoc fashion, ${ }^{53}$ relating to a concrete event or set of events, but rarely in systematic and conceptual fashion. Even then it is often forgotten that organisations themselves are supposed to exercise delegated tasks, delegated to them by their member states. Thus one might get the picture where a group of states sets up organisation X, another group (albeit with overlapping membership) sets up organisation $\mathrm{Y}, \mathrm{X}$ and $\mathrm{Y}$ together further delegate a task to their newly created joint venture entity $Z$. Those initial member states may well be in control of what $X$ and $Y$ do (nominally if not always in real life); but how can they control what $\mathrm{Z}$ does? Thus, $\mathrm{Z}$ becomes, quite literally, uncontrollable.

It is here also that many of the above-mentioned questions come together. Issues of attribution can be made easier, or at least more transparent, by having clearer governance structures, by having well-developed rules on treaty-making powers and procedures. If we expect our international organisations to abide by the Rule of Law (whichever particular version thereof) then nothing less will do. It is rather discouraging to see international organisations advertising the virtues of the Rule of Law but wrapping themselves in layers of legal opacity and uncertainty just because doing so may make it easier to reach policy goals. Whether it is actually the case that organisations shirking the Rule of Law are more effective remains to be seen at any rate. The effectiveness of international organisations is an empirical issue that can only meaningfully be discussed against the background of a solid perspective on what it is they are supposed to do and how they are supposed to do it. The assessment requires a solid normative perspective as well, as certainly not all paths to effectiveness are equally acceptable.

\section{THEORETICAL REFLECTIONS}

So, what then is it that international organisations are supposed to be doing? There is no clear-cut answer to this (and most assuredly no general answer), but the usual answer would be to claim that organisations should help their member states in achieving the functions for which they were created. This usual answer goes by the name of functionalism, and has been around for well over a century by now, having been first developed in serious manner by Paul Reinsch in a series of writings predominantly published between 1907 and 1911. ${ }^{54}$

Functionalism as developed by Reinsch and further developed by others focused initially solely on the effects of the work of international organisations on their member states. Organisations were not supposed to affect third parties in any way - indeed, strictly speaking, they could not do so, as they are based on treaties and the law of treaties has an undisputed 'third party rule': pacta tertiis nec nocent nec prosunt. Third parties could not be affected and should not be affected, and it was in line

53. See D Sarooshi, The United Nations and the Development of Collective Security: The Delegation by the Security Council of Its Chapter VII Powers (OUP, Oxford 1999); NM Blokker, 'Is the Authorization Authorized? Powers and Practice of the UN Security Council to Authorize the Use of Force by "Coalitions of the Able and Willing"" (2000) 11 EJIL 541. 54. See PS Reinsch, Public International Unions, Their Work and Organization: A Study in International Administrative Law (Ginn and Company, Boston and London 1911); for discussion, see J Klabbers, 'The Emergence of Functionalism in International Institutional Law: Colonial Inspirations' (2014) 25 EJIL 645. 
with the spirit of the time that the citizens of member states were not considered directly affected by international law in any way, and thus considered not to be affected by treaties setting up international organisations or, accordingly, by the work of those organisations. ${ }^{55}$

This position was ultimately untenable in practice, but the theory was never really adapted. To this day, functionalism has a hard time explaining the effect of international organisations on individuals, as well as on other third parties. The reason for this is that at the end of the day, functionalism has remained a theory about relations between the organisation and its member states - other dimensions simply do not, and possibly cannot, enter the picture. As a result, there are at least two large sets of dynamics that functionalism has little to say about. ${ }^{56}$ It has little traction, first, in discussions on relations between various organs of organisations, on institutional balance, checks and balances, or judicial review. Likewise, it has little to say in discussions on relations between the organisation and its staff members - these too do not fit neatly (or at all, really) with functionalism, and it is no coincidence that the literature looks for inspiration to constitutional or public law, far removed from functionalism. Secondly, as alluded to, relations between organisations and the world external to them (be it non-member states, citizens, civil society, or other organisations) do not fit the theory.

It follows, that the increasing autonomy of international organisations poses a huge challenge for the existing theoretical framework. If functionalism as a theory is limited to discussing and perhaps explaining relations between the organisation and its member states, then how can it even begin to say something meaningful on relations between organisations inter se, all the more so since the notion of delegation remains underdeveloped? And even more dramatically, if those relations between organisations inter se are of increasing importance, then what good is functionalism now? It is quite possibly not much of an exaggeration to state that functionalism has passed its sell-by-date, and needs to be replaced by something else.

However it remains unclear what this 'something else' could be. One option that has been floated in the literature (but discarded by the person doing the floating) ${ }^{57}$ is to draw the analogy with Robert Cover's notion of nomos and narrative, a complicated story boiling down to the suggestion that behind every normative system (and organisations could be conceived as such) stands a substantive story, a narrative, outlining why precisely this group of people adopted that normative system. Transposed to international organisations though, this assumes too much. International organisations are not quite analogous to the kind of organic political communities Cover discusses as narrative-based. ${ }^{58}$

Alternatively, one could think of the transformation of institutions into increasingly autonomous actors in system-theoretic terms, following the sociology of Niklas

55. These were, lest it be forgotten, the heydays of dualism, and dualism itself was claimed to rest on the empirical foundation that international law only affected states in their mutual relations. See H Triepel, 'Les rapports entre le droit interne et le droit international' (1923) 1 Recueil des Cours 73. Conversely, a contemporary study of the third party problem at no point enters into discussions of individuals as third parties - even the section on 'international legislation' remains limited to discussing majoritarian law-making between states. See RF Roxburgh, International Conventions and Third States (Longmans, Green \& Co, London 1917) 99-101. 56. See J Klabbers, 'Theorising International Organisations' in A Orford and F Hoffmann (eds), The Oxford Handbook on the Theory of International Law (OUP, Oxford 2016) 618.

57. See Dunoff, 'A New Approach to Regime Interaction' (n 18) 144-56.

58. The reference is to R Cover, 'The Supreme Court 1982 Term - Foreword: Nomos and Narrative' (1983) 97 HLR 4. 
Luhmann as further developed by Gunther Teubner. The latter identifies functional regimes (security, health, human rights et cetera), and at first sight it seems that this has considerable bearing on the practices of international organisations. These, after all, are often discussed in similar terms, as manifesting or symbolising those functional regimes. The global health regime, on such an analysis, is spearheaded by the WHO; the security regime by the UN, the trading regime by the WTO. All this is fair enough, but leaves one pivotal question unanswered, and that is the question of infra-regime relations and competition within regimes. The trading regime may still be spearheaded by the WTO, but how does this explain the emergence of the so-called megaregional agreements, or the competition between the WTO and the various regional trading arrangements, or even the constipation of the Doha Round? Likewise, the security regime may find the UN at its apex, but its mere existence cannot explain the relations between the UN and other entities, whether NATO or the Organization for Security and Co-operation in Europe (OSCE) in Europe or the African Union and the Economic Community of Western African States (ECOWAS) in Africa.

A third possible option is more challenging still and that is to re-imagine the world as a civitas mundi which would delegate tasks on various levels to various entities. Some tasks would be entrusted to states, as trustees of humanity, ${ }^{59}$ but in a similar vein other tasks could be entrusted to organisations: functionally but not territorially based. This would result in the decoupling of international organisations from their member states - on such a reading, member states would be little more than passengers, but would not be the fons et origo of the organisation, and thus the organisation would no longer be thought of as exercising a function delegated by member states. They would remain functional, but the function would be conferred by someone else: international society at large, rather than particular member states.

One normative advantage of such a re-imagining would be that it might allow for distinctions between organisations devoted to the common good, and those that serve an immediately recognisable particular interest. The former might include organisations such as the WHO, whereas the Organization of the Petroleum Exporting Countries (OPEC) might be emblematic for the latter - it always strikes as odd that under functionalist theory, these widely diverging entities merit identical treatment in the eyes of the law. ${ }^{60}$

Still, such a re-imagining of the world requires a leap of faith or two. It requires the conviction that from a civitas mundi tasks could legitimately be delegated to entities whether territorially based (states) or functionally based (international organisations). ${ }^{61}$ It also still entails some kind of functionalism, perhaps even stronger than is currently the case. After all, if the WHO is not to be considered a vehicle for its member states but seen to perform a task emanating from global consent to be exercised in the common good, then surely any claim that would (potentially) interfere with its performance would be considered inappropriate. On such a theory, holding the WHO accountable would be akin to organisational blasphemy - the result would be hyper-functionalism. ${ }^{62}$

59. For a recent exploration, see E Benvenisti, 'Sovereign as Trustees of Humanity: On the Accountability of States to Foreign Stakeholders' (2013) 107 AJIL 295.

60. See further J Klabbers, 'Unity, Diversity, Accountability: The Ambivalent Concept of International Organisation' (2013) 14 Melbourne J of Int'l L 149.

61. Such a conception underlies H Kelsen, Principles of International Law (Rinehart \& Co, New York 1952).

62. On hyper-functionalism, see also J Klabbers, 'Functionalism, Constitutionalism and the United Nations' in A Lang Jr and A Wiener (eds), Handbook on Global Constitutionalism (Edward Elgar, Cheltenham forthcoming). 


\section{TO CONCLUDE}

What is obvious is that the law of international organisations is engaged in a constant process of transformation, and the current transformation, revolving around autonomy and accountability, can be traced back to at least the 1980s. The surprising thing though is twofold. It is surprising, first, that it took so long for people to slowly start to question the merits of functionalist thought despite the fact that as early as the 1930s it became visible that functionalism has its limits. Surely, by way of example, the UK attempt to expel Liberia from the League of Nations in the 1930s owes little to functionalist thought. ${ }^{63}$ It may have stemmed from good intentions (the charitable interpretation) or from political expediency (less charitable), but it can only with great difficulty be described as an emanation of functionalism. And much the same applies to many interludes and incidents in the law and practice of international organisations.

Second, what also surprises is that despite the fact that it has been clear for at least some four decades that functionalism has its limits, very little has been done about it: international organisations law is still, by and large, enthralled by functionalist thought. And empirical problems have done little to counter this enchantment, not even the circumstance that functional tasks are no longer exclusively assigned to international organisations but, instead, end up with other entities (informal networks and contact groups, under-institutionalised Meetings of Parties, transnational actors of uncertain provenance), or the circumstance that for the major issues of the day (financial regulation, environmental protection, cyber-governance, the platform economy) no comprehensive international organisations exist. Functionalism may not have all that much traction, but is remarkably resilient.

One may wonder what causes this. Partly, it may be speculated, it owes something to the reproduction of knowledge. Those who teach and practice international organisations law have always been imbued with functionalism, and thus can hardly help but transmit it to their pupils and employees. Partly, it may also have something to do with its normative appeal. If functionalism does indeed promise the salvation of mankind, evidence to the contrary notwithstanding, then who would want to stand in its way? But the biggest problem may be a lack of political imagination. Somehow, we are programmed to think that global governance can only be divided in two ways; either territorial, or functional (or perhaps a combination of the two). It is no coincidence that people immediately think of a new international organisation to solve an international issue, as noted above, and it is no coincidence that one of the most sophisticated attempts to re-imagine the Westphalian state system ended up presenting as new something uncannily resembling that very same Westphalian state system: ${ }^{64}$ it proves very difficult to escape established ways of thinking and established vocabularies.

And thus the curious condition presents itself that just when international organisations are shedding their ontological anxieties and are being taken seriously as political actors in their own right, the legal 'operating system' that has governed their work for more than a century is losing traction. Functionalism does little to explain the interactions between increasingly autonomous international organisations, acting on their own and without much input by member states; instead, international organisations lawyers will need to start to look elsewhere in order to make sense of this institutional transformation.

63. For brief discussion, see A Duxbury, The Participation of States in International Organisations: The Role of Human Rights and Democracy (CUP, Cambridge 2011) 107.

64. This refers to A Linklater, The Transformation of Political Community: Ethical Foundations of the Post-Westphalian Era (Polity, Cambridge 1998). 